\title{
Efficacy of Treatments in Nonarteritic Ischemic Optic Neuropathy: A Systematic Review and Meta-Analysis
}

\author{
Krisztina Lantos ${ }^{1}$, Zsuzsa Réka Dömötör ${ }^{2}{ }^{\oplus}$, Nelli Farkas ${ }^{3}$, Szabolcs Kiss ${ }^{4,5}{ }^{\oplus}$, Zsolt Szakács ${ }^{5}{ }^{\oplus}$, \\ András Garami ${ }^{5}{ }^{(0)}$, Gábor Varga ${ }^{6}{ }^{(\mathbb{D}}$, László Lujber ${ }^{7}$, Reem Kanaan ${ }^{8}$, Péter Hegyi ${ }^{5}$, Gergely Fehér 9 \\ and Valéria Gaál $1, * \mathbb{D}$
}

\section{check for}

Citation: Lantos, K.; Dömötör, Z.R.

Farkas, N.; Kiss, S.; Szakács, Z.;

Garami, A.; Varga, G.; Lujber, L.;

Kanaan, R.; Hegyi, P.; et al. Efficacy

of Treatments in Nonarteritic

Ischemic Optic Neuropathy: A

Systematic Review and

Meta-Analysis. Int. J. Environ. Res. Public Health 2022, 19, 2718. https:// doi.org/10.3390/ijerph19052718

Academic Editor: Eleanor Kane

Received: 9 December 2021

Accepted: 22 February 2022

Published: 26 February 2022

Publisher's Note: MDPI stays neutral with regard to jurisdictional claims in published maps and institutional affiliations.

Copyright: (C) 2022 by the authors. Licensee MDPI, Basel, Switzerland. This article is an open access article distributed under the terms and conditions of the Creative Commons Attribution (CC BY) license (https:// creativecommons.org/licenses/by/ $4.0 /)$.
1 Department of Ophthalmology, Medical School, University of Pécs, 7632 Pécs, Hungary; lantos.krisztina@pte.hu

2 Department of Ophthalmology, Medical School, University of Debrecen, 4032 Debrecen, Hungary; reka.zsuzsa@gmail.com

3 Institute of Bioanalysis, Medical School, University of Pécs, 7624 Pécs, Hungary; farkas.nelli@gmail.com

4 Doctoral School of Clinical Medicine, University of Szeged, 6720 Szeged, Hungary; kissszabolcs1995@gmail.com

5 Institute for Translational Medicine, Medical School, University of Pécs, 7624 Pécs, Hungary; szaki92@gmail.com (Z.S.); andras.garami@aok.pte.hu (A.G.); hegyi.peter@pte.hu (P.H.)

6 Department of Oral Biology, Faculty of Dentistry, Semmelweis University, 1089 Budapest, Hungary; varga.gabor@dent.semmelweis-univ.hu

7 Department of Otorhinolaryngology, Medical School, University of Pécs, 7621 Pécs, Hungary; lujber.laszlo@pte.hu

8 Department of Public Health Medicine, Medical School, University of Pécs, 7624 Pécs, Hungary; rkanaan3@gmail.com

9 Department of Primary Health Care, Medical School, University of Pécs, 7624 Pécs, Hungary; feher.gergely@pte.hu

* Correspondence: gaal.valeria@pte.hu; Tel.: +36-72-504-210

Abstract: Background: Nonarteritic Anterior Ischemic Optic Neuropathy (NAION) is the second most common cause of optic nerve-related permanent visual loss in adults. Aim: We aimed to analyze the efficacy of the noninvasive and minimally invasive therapeutic options of NAION. Methods: We performed a systematic literature search in MEDLINE, EMBASE, and CENTRAL from inception to 10 June 2019 to identify the studies that report on the effect of different therapies on visual acuity (VA) and visual field (VF). Weighted mean difference (WMD) with 95\% confidence interval (CI) was calculated for these outcomes. The efficacy of steroids was investigated in quantitative, oxygen, steroid plus erythropoietin (EPO), levodopa/carbidopa, memantine, and heparin-induced extracorporeal LDL/ fibrinogen precipitation (HELP) therapies and other therapeutic modalities in qualitative synthesis. Results: Thirty-two studies were found to be eligible. We found that steroid therapy compared to control did not improve VA $(p=0.182, \mathrm{WMD}=0.14,95 \% \mathrm{CI}:-0.07,0.35)$ or VF $(p=0.853, \mathrm{WMD}=0.16,95 \% \mathrm{CI}:-1.54,1.86)$. Qualitative analysis could be performed for oxygen, steroid plus EPO, and HELP as well, however, none of them showed VA and VF benefit. Two individual studies found memantine and levodopa beneficial regarding VA. Conclusion: Our systematic review did not reveal any effective treatment. Further investigations are needed to find therapy for NAION.

Keywords: nonarteritic ischemic optic neuropathy; NAION; meta-analysis

\section{Introduction}

Nonarteritic ischemic optic neuropathy (NAION) is the most common acute optic neuropathy in patients over 50 years of age. It affects 2 to 10 persons per 100,000 [1]

NAION is characterized by sudden painless loss of vision and visual field defects, an arcuate or altitudinal defect particularly in the inferior visual field or other patterns of 
nerve fiber bundle defect. Clinically, it is characterized by segmental swelling of the optic disc, which in several months leads to optic atrophy.

The exact etiology of NAION is unknown. The pathogenesis of NAION is generally accepted as a decrease in perfusion pressure to the optic nerve head resulting in acute ischemic infarction of the optic nerve and secondary inflammation, with later apoptosis of the retinal ganglion cells. Some authors believe that it shows an analogy with the etiopathogenesis of central nervous system multiple microembolism. Multiple embolisms occurring in the lateral end branch of the posterior ciliary artery, which supplies the optic disc, are most likely to play a central role in the development of the condition. Undetected or untreated hypertension, atheromatosis, and diabetes mellitus are the most important underlying diseases among patients suffering from NAION [2]. The fellow eye often becomes affected. Incidence of fellow eye NAION was 15\% 5 years after the first eye was affected. In younger patients, the risk of fellow eye involvement seems to be higher with $35 \%$ involvement of the second eye within 7 months [3].

There is no generally accepted treatment for NAION. Most of the current medical therapeutic approaches are empirical, and mainly target the possible causes of ischemia, such as thrombosis, insufficient blood supply, and inflammation, or apply neuro-protective and neuro-regenerative agents, because retinal ganglion cell death is the final consequence.

The available literature of the possible treatment of NAION is quite diverse and controversial. Several trials evaluated the efficiency of steroids applying systemic (oral or intravenous) or intravitreal administration on NAION [1,4-14]. There are some studies of levodopa efficacy in the improvement of visual function in NAION patients [15-18]. Other studies addressed the neuroprotective actions of different agents, such as erythropoietin (EPO), brimonidine, and memantine, targeting the preservation of neuronal function $[5,19-22]$.

The microcirculatory vasodilator PGE1 was also investigated as a therapeutic agent as well as anticoagulant drugs such as heparin and warfarin [7,23]. A significant improvement of the hemorheological abnormalities was described using heparin-induced extracorporeal LDL/fibrinogen precipitation (HELP), which eliminates fibrinogen, LDL, cholesterol, and triglycerides from blood, so the plasma viscosity decreases and the microcirculation improves. The effectiveness of HELP treatment was assessed by the visual function of patients affected by NAION [24-26]. Additionally, two published case series showed that intravitreal treatment with anti-VEGF agent (ranibizumab) $[27,28]$ had beneficial effects for NAION. In contrast, another study did not find difference between intravitreal bevacizumab and the natural history in change of visual function in patients [29].

In the treatment of NAION, some studies have found results in surgical solutions such as optic nerve decompression, transvitreal optic neurotomy, and pars plana vitrectomy with removal of epipapillary adhesions. In the Ischemic Optic Neuropathy Decompression Trial (IONDT), the results of the treated eyes were worse than those of the untreated eyes and $42 \%$ of cases showed improvement in visual acuity spontaneously. Optic neurotomy and vitrectomy have been examined in a small number of studies and their results are not suitable for comparative analysis [3]. There is little chance of surgical solutions spreading, so the aim of this systematic review was to investigate the efficacy of noninvasive and minimally invasive treatment options for NAION.

\section{Materials and Methods}

Our meta-analysis was conducted according to the recommendations of the Cochrane Handbook for Systematic Reviews of Interventions and was registered in PROSPERO International Prospective Register of Systematic Reviews (registration number CRD42018102521). Preferred Reporting Items for Systematic Reviews and Meta-Analysis (PRISMA) guidelines were applied to report our results [30]. We deviated from the protocol in that we also narratively analyzed non-comparative studies, because we wanted to show a more complex view about therapeutic difficulties. 


\subsection{Eligibility Criteria}

We created our scientific question following the population-intervention-controloutcomes (PICO) framework: (P) our population consisted of patients with nonarteritic anterior ischemic optic neuropathy, (I) who received a therapeutic intervention (corticosteroids or levodopa with carbidopa or erythropoietin, pentoxifylline, brimonidine, memantine, prostaglandin E1, ranibizumab, bevacizumab, oxygen, heparin-induced extracorporeal LDL/fibrinogen precipitation (HELP), Fasudil), (C) compared with no treatment or placebo, and our $(\mathrm{O})$ outcomes were improvement of visual acuity (VA), change in visual field (VF), and retinal nerve fiber layer (RNFL) thickness. Studies were included in our qualitative synthesis if they reported the mentioned therapeutic interventions even if they were not comparative studies. Studies that used the Humphrey visual field analyzer were included in our quantitative analysis of VF. We compared the mean deviation (MD) values of these studies. Studies in which the treatment was not initiated within 1 month after the onset of NAION or that applied surgical interventions were excluded.

\subsection{Search and Selection Strategy}

Our systematic search was performed in MEDLINE (via PubMed), EMBASE and CENTRAL (Cochrane Central Register of Controlled Trials) from inception to 10 June 2019. Our search query was '((non-arteritic OR nonarteritic) AND anterior AND ischemic AND optic AND neuropathy) OR NA-AION OR N-AION OR NAION'. No search filters were applied.

The results of our search were imported to and processed with the EndNote X7.4 software (Clarivate Analytics, Philadelphia, PA, USA). After removing duplicates automatically and manually, the studies were screened by title, then by abstract, and finally by full text by two independent investigators (K.L., V.G.). Disagreements were resolved by consensus.

\subsection{Data Extraction}

Numeric data were extracted independently by two reviewers (K.L. and V.G.) and entered into a purpose-designed Excel datasheet (Office 365, Microsoft, Redmond, WA, USA). We extracted data of the author of the study, year of publication, study design, details of the intervention, length of follow-up, number of patients, and the outcomes: VA, VF, and RNFL thickness, before the treatment and after at specified times. Any discrepancies were resolved by consensus.

\subsection{Statistical Analysis}

For data synthesis, we used the methods recommended by the working group of the Cochrane Collaboration [31]. Random effects-models by DerSimonian and Laird [32] were used to conduct a meta-analysis to assess the effect of different therapies on VA and VF. In the case of VA as a continuous variable, weighted mean difference (WMD) and 95\% confidence interval (CI) of logMAR values were estimated. The VA was reported in LogMAR values in all but one study, in which data had to be converted to LogMAR values [33].

For VA as a categorical variable, 'improved' and 'not improved' categories were used to calculate pooled odds ratios with $95 \%$ CI. In case of VF as a continuous variable WMD and $95 \%$ CI of mean deviation values were estimated. Because in some studies there were no events observed, we performed a continuity correction recommended in the Cochrane Handbook and proposed by Sweetin et al. [34] to overcome the difficulty of dividing by 0 . We calculated WMD for the therapies and outcomes with sufficient data for the analysis. The other studies were summarized narratively.

When the number of studies was sufficient for statistical analysis, publication bias was evaluated by visual inspection of funnel plots and test $\mathrm{f} \mathrm{H} 0$. Heterogeneity was tested using Cochrane's Q and I2 statistics.

We performed all meta-analytic calculations with STATA 16 statistical software (STATA Corp. 2019. Stata Statistical Software: Release 16. College Station, TX, USA: StataCorp LLC.). 


\subsection{Risk of Bias Assessment}

The risk of bias assessment was done at the study level and then summarized narratively. We used the revised Cochrane Collaboration's risk-of-bias tools for randomized trials-RoB 2 tool [35] and non-randomized trials-ROBINS-I tool [36]. The tools were assessed by three investigators (K.L., V.G., Z.R.D.). Disagreements were resolved by consensus.

\subsection{Quality of Evidence}

The Grades of Recommendation Assessment, Development, and Evaluation (GRADE) approach was used to assess the certainty of evidence regarding the outcomes. [37]. It was assessed by two investigators (K.L., Z.R.D.).

\section{Results}

\subsection{Study Selection and Characteristics of the Studies Included}

The results of the literature search are illustrated by the flowchart in Figure 1. A total of 2570 articles were identified and 32 of these were included in qualitative synthesis and 6 of these with 524 patients in quantitative analysis. The summary of the characteristics of the studies included in our analysis is shown in Table 1.

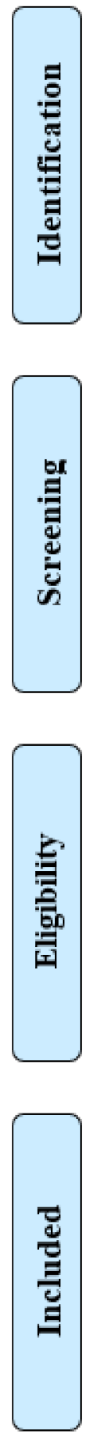

Records identified through database searching

$(\mathrm{n}=2569)$

\section{Additional records identified through other sources} $(\mathrm{n}=1)$

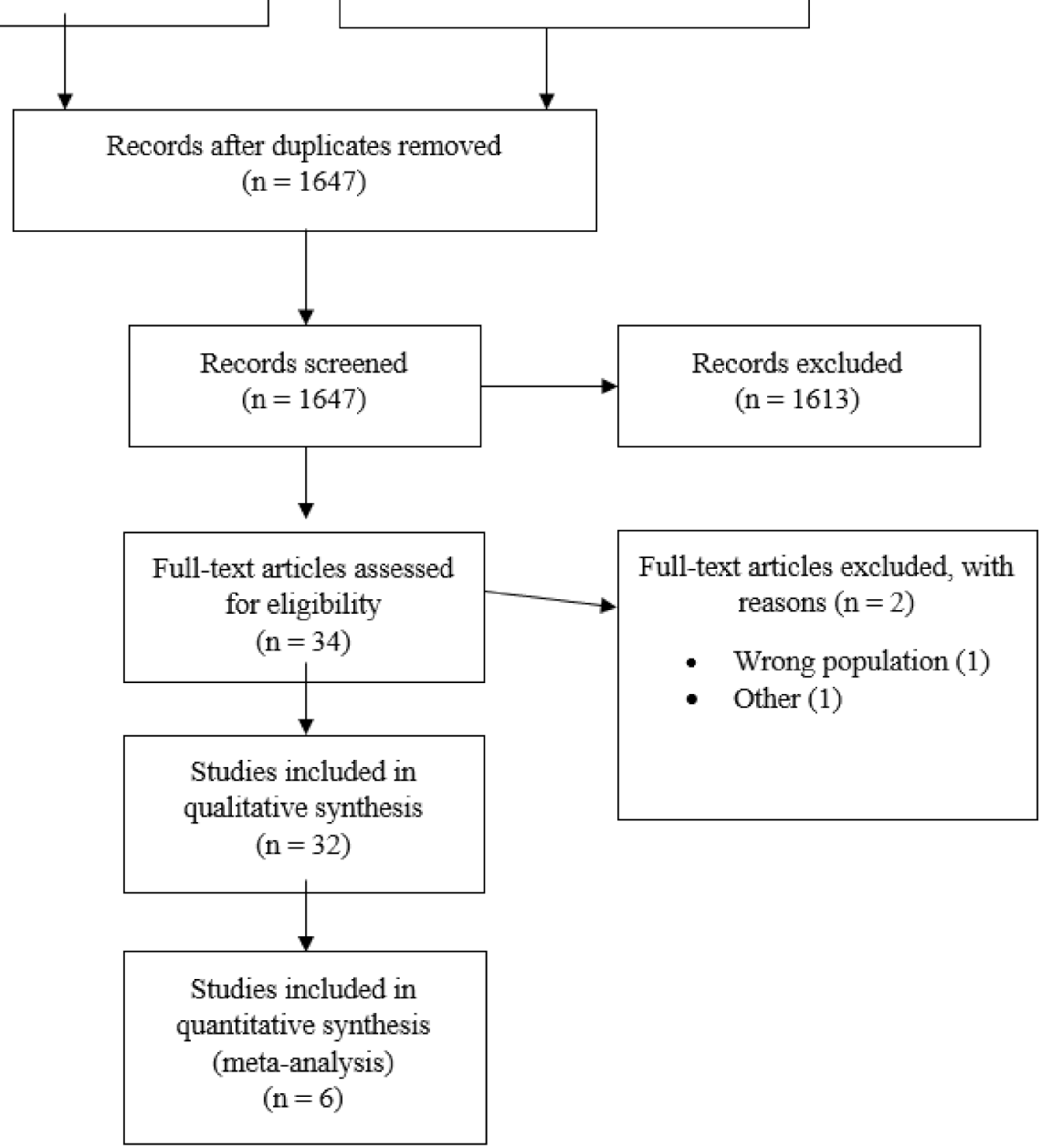

Figure 1. PRISMA Flowchart. 
Table 1. Characteristics of the studies included.

\begin{tabular}{|c|c|c|c|c|}
\hline Study, Year & Study Design & Interventions & $\begin{array}{c}\text { No.of } \\
\text { Participants }\end{array}$ & $\begin{array}{c}\text { VA } \\
\text { Follow-Up } \\
\text { (Months) }\end{array}$ \\
\hline \multirow{2}{*}{ Rebodella et al., 2013 [4] } & \multirow{2}{*}{ retrospective cohort study } & prednisolone PO & 10 & \multirow{2}{*}{6} \\
\hline & & untreated & 27 & \\
\hline \multirow{3}{*}{ Pakravan et al., 2016 [1] } & \multirow{3}{*}{ randomized clinical trial } & $\begin{array}{l}\text { iv. methylprednisolone, } \\
\text { prednisolone PO }\end{array}$ & 30 & \multirow{3}{*}{6} \\
\hline & & $100 \%$ normobaric oxygen & 30 & \\
\hline & & untreated & 30 & \\
\hline \multirow[t]{2}{*}{ Kinori et al., 2014 [6] } & \multirow[t]{2}{*}{ retrospective cohort study } & $\begin{array}{l}\text { iv. methylprednisolone, } \\
\text { prednisolone PO }\end{array}$ & 24 & 22 \\
\hline & & untreated & 24 & 36 \\
\hline \multirow[t]{2}{*}{ Steigerwalt et al., 2008 [7] } & \multirow[t]{2}{*}{ prospective cohort study } & $\begin{array}{l}\text { i.v methylprednisolone+ } \\
\text { PGE1 }\end{array}$ & 8 & 6 \\
\hline & & prednisolone PO & 7 & \\
\hline \multirow{3}{*}{ Pakravan et al., 2017 [5] } & \multirow{3}{*}{ prospective cohort study } & $\begin{array}{l}\text { iv. methylprednisolone + } \\
\text { EPO, prednisolone PO }\end{array}$ & 40 & \multirow{3}{*}{6} \\
\hline & & $\begin{array}{l}\text { iv. methylprednisolone, } \\
\text { prednisolone PO }\end{array}$ & 43 & \\
\hline & & untreated & 30 & \\
\hline \multirow{2}{*}{ Radio et al., 2014 [8] } & \multirow{2}{*}{ retrospective cohort study } & intravitreal triamcinolone & 21 & \multirow{2}{*}{6} \\
\hline & & untreated & 15 & \\
\hline \multirow{2}{*}{ Kaderli et al., 2007 [9] } & \multirow{2}{*}{ retrospective cohort study } & intravitreal triamcinolone & 4 & $12-15$ \\
\hline & & untreated & 6 & $9-12$ \\
\hline Hayreh et al., 2008/1 [10] & \multirow{2}{*}{ retrospective cohort study } & prednisolone PO & 312 & \multirow{2}{*}{6} \\
\hline Hayreh et al., 2008/2 [38] & & untreated & 301 & \\
\hline \multirow{2}{*}{ Saxena et al., 2018 [11] } & \multirow{2}{*}{$\begin{array}{l}\text { randomized, double-blind } \\
\text { placebo-controlled trial }\end{array}$} & prednisolone $\mathrm{PO}$ & 19 & \multirow{2}{*}{6} \\
\hline & & untreated & 19 & \\
\hline \multirow[b]{2}{*}{ Prokosch et al., 2014 [14] } & \multirow[b]{2}{*}{ randomized controlled trial } & iv+per os pentoxifylline & 30 & \multirow[b]{2}{*}{6} \\
\hline & & $\begin{array}{l}\text { iv+per os pentoxifylline }+ \\
\text { fluocortolone }\end{array}$ & 30 & \\
\hline Vidovic et al., 2015 [12] & prospective case series & methylprednisolone PO & 38 & 6 \\
\hline Yaman et al., 2008 [13] & case series & intravitreal triamcinolone & 4 & 3 \\
\hline Modarres et al., 2011 [19] & prospective case series & intravitreal EPO & 31 & 6 \\
\hline \multirow{2}{*}{ Johnson et al., 1996 [15] } & \multirow{2}{*}{$\begin{array}{l}\text { randomized, double-masked } \\
\text { placebo-controlled trial }\end{array}$} & levodopa/carbidopa & 10 & \multirow{2}{*}{6} \\
\hline & & untreated & 10 & \\
\hline Iyttle ot al 2015 [18] & retrosnective cohort study & levodopa/carbidopa & 33 & $e$ \\
\hline , Lytile el alo, 2010 [10] & Ietiospective conorit sinay & untreated & 26 & 8 \\
\hline Simcol ot ol 2005 [16] & randomized, & levodopa/carbidopa & 12 & 11 \\
\hline 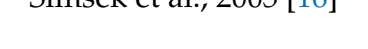 & placebo-controlled trial & untreated & 12 & 10 \\
\hline Johncon ot ol 2000 [17] & retrosnective chort study & levodopa/carbidopa & 18 & 6 \\
\hline jonnson el al., 2000 [1/] & Ietrospective contorit stuay & untreated & 19 & $\mathrm{~b}$ \\
\hline Bajin et al., 2011 [27] & retrospective case series & intravitreal ranibizumab & 4 & 3 \\
\hline Saatsi et al., 2013 [28] & retrospective case series & intravitreal ranibizumab & 17 & 12 \\
\hline
\end{tabular}


Table 1. Cont.

\begin{tabular}{|c|c|c|c|c|}
\hline Study, Year & Study Design & Interventions & $\begin{array}{c}\text { No.of } \\
\text { Participants }\end{array}$ & $\begin{array}{c}\text { VA } \\
\text { Follow-Up } \\
\text { (Months) }\end{array}$ \\
\hline Prescott et al., 2012 [39] & retrospective case series & intravitreal bevacizumab & 5 & inconsistent \\
\hline \multirow{2}{*}{ Rootman et al., 2013 [29] } & \multirow{2}{*}{$\begin{array}{l}\text { non-randomized } \\
\text { controlled trial }\end{array}$} & intravitreal bevacizumab & 17 & \multirow{2}{*}{6} \\
\hline & & untreated & 8 & \\
\hline \multirow{2}{*}{ Fazzone et al., 2003 [20] } & \multirow{2}{*}{ retrospective cohort study } & topical brimonidine & 14 & \multirow{2}{*}{$2-3$} \\
\hline & & untreated & 17 & \\
\hline \multirow{2}{*}{ Wilhelm et al., 2006 [21] } & \multirow{2}{*}{$\begin{array}{l}\text { randomized, double masked, } \\
\text { placebo-controlled trial }\end{array}$} & topical brimonidine & 11 & \multirow{2}{*}{$3-3,5$} \\
\hline & & untreated & 18 & \\
\hline \multirow{2}{*}{ Haas et al., 1997 [24] } & \multirow{2}{*}{ randomized, controlled trial } & HELP & 19 & \multirow{2}{*}{3} \\
\hline & & hemodilution & 21 & \\
\hline Ramunni et al., 2005 [25] & case series & HELP & 11 & 3 \\
\hline Haas et al., 1994 [40] & retrospective case series & hemodilution & 24 & 24 \\
\hline \multirow{2}{*}{ Guerriero et al., 2009 [26] } & \multirow{2}{*}{ prospective case series } & LDL apheresis & 10 & \multirow{2}{*}{6} \\
\hline & & conventional therapy & 10 & \\
\hline Bojic et al., 1994 [41] & case series & hyperbaric oxygen & 9 & 6 \\
\hline Aftab et al., 2006 [23] & $\begin{array}{l}\text { prospective interventional } \\
\text { pilot study }\end{array}$ & iv Heparin, Warfarin PO & 24 & 6 \\
\hline Sanjari et al., 2016 [42] & case series & intravitreal Fasudil & 13 & 3 \\
\hline \multirow{2}{*}{ Esfahani et al., 2011 [22] } & \multirow{2}{*}{$\begin{array}{l}\text { randomized, double-masked } \\
\text { controlled trial }\end{array}$} & memantine PO & 25 & \multirow{2}{*}{6} \\
\hline & & untreated & 22 & \\
\hline
\end{tabular}

Most of the included studies contained data on the change in the VA during the study period. Fewer studies provided data on the change between the initial and final VA values. Due to the lack of RNFL thickness data in most of the included studies, we could not analyze this outcome.

\subsection{Effects of Steroid Therapy on Visual Acuity}

First, we analyzed VA as a continuous variable (Figure 2). We imported or converted every VA value in LogMAR and in all the studies included, the follow-up period lasted for at least 6 months.

Data regarding steroid therapy showed that steroids did not significantly improve VA compared to the control group ( $p=0.182, \mathrm{WMD}=0.14,95 \% \mathrm{CI}:-0.07,0.35)$. Heterogeneity among these studies was moderate $\left(\mathrm{I}^{2}=63.5 \%, p=0.027\right)$.

The same results were obtained analyzing VA as a categorical variable (Figure 3 ). The VA of patients treated with steroids did not show significant improvement at the end of the follow-up compared to the control group ( $p=0.149$, OR $=1.77,95 \%$ CI: $0.81,3.84$ ). Heterogeneity was moderate among these studies, too $\left(\mathrm{I}^{2}=58.3 \%, p=0.035\right)$.

\subsection{Effects of other Therapies on Visual Acuity}

We identified only one eligible study investigating the effects of oxygen therapy on VA. In this study, oxygen therapy did not significantly improve the VA of patients compared to the control group [1].

We included one article which investigated the effect of combined intravenous erythropoietin (EPO) and corticosteroid therapy. Steroid plus EPO did not improve the VA significantly [5]. 
One eligible study investigated the effect of memantine therapy [22]. Analyzing the results as continuous variables memantine showed improved VA compared to the control group, but as a categorical variable, memantine did not significantly improve the VA [22]

We identified a study that compared the effect of levodopa with carbidopa to placebo on VA. Johnson et al. revealed a significant improvement of VA in the levodopa, carbidopa group [17].

Lyttle et al. found that levodopa with carbidopa improved the central VA of the participants with an initial VA of 20/60 or worse. The mean change in VA of the patients with better VA was not reported so we could not include these data in our analysis. Due to inconsistent data reporting in tables vs. plain text, we did not include their results in our analysis of VA as a categorical variable [18].

Haas et al. investigated the effect of heparin-induced extracorporeal LDL/fibrinogen precipitation. The improvement of VA did not differ significantly between the HELP and the hemodilution group [24].

During categorization of the eligible studies, two articles $[10,17]$ could not be used, because patients with better than 20/40 initial VA had no further data on the improvement of VA. We conducted a meta-analysis without the study by Hayreh et al. [10,38] and the result was very similar without a significant decrease in the heterogeneity among the studies (Supplementary Figure S1).

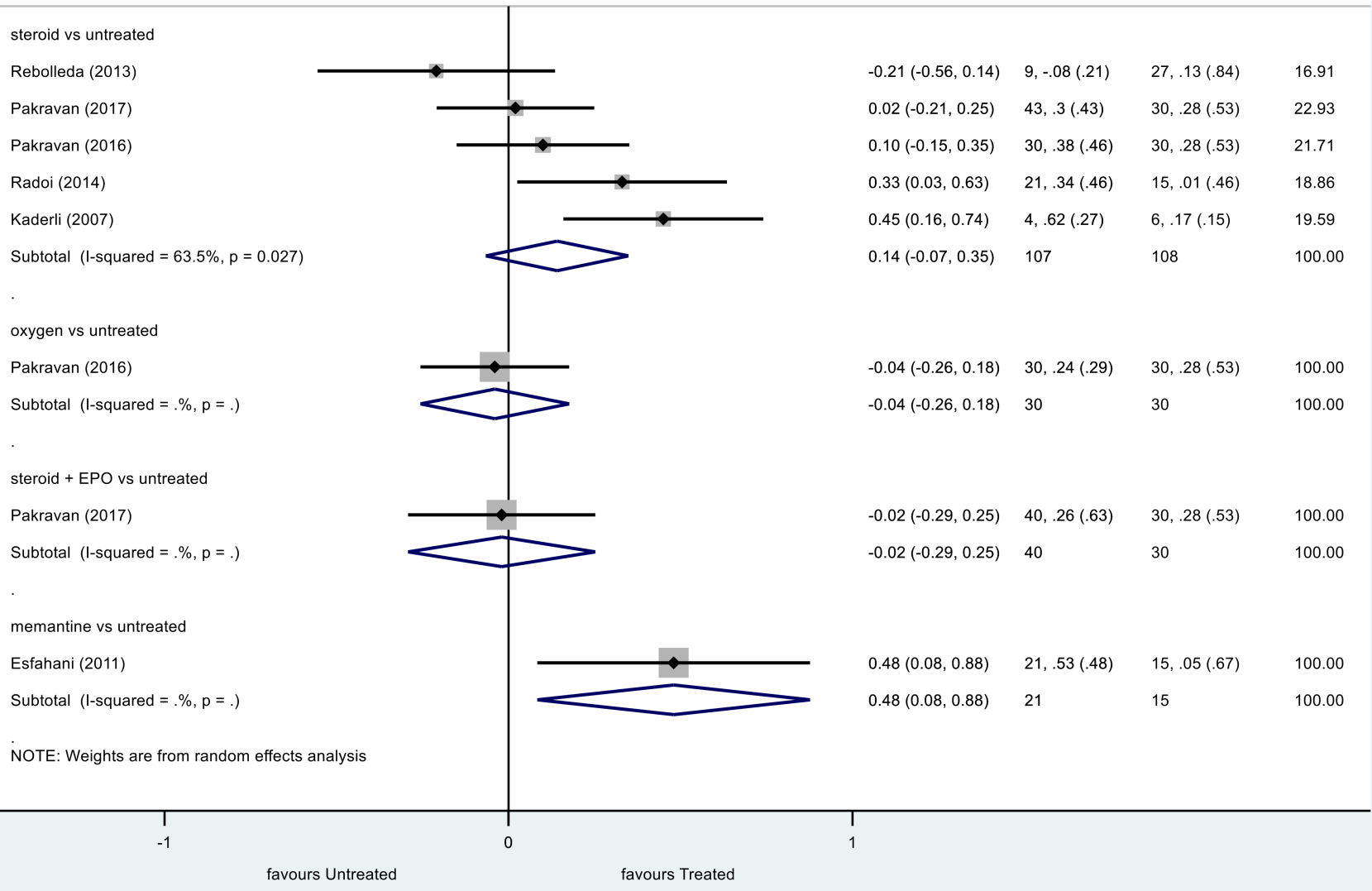

Figure 2. Comparison of interventions to no treatment regarding visual acuity (as a continuous variable). 


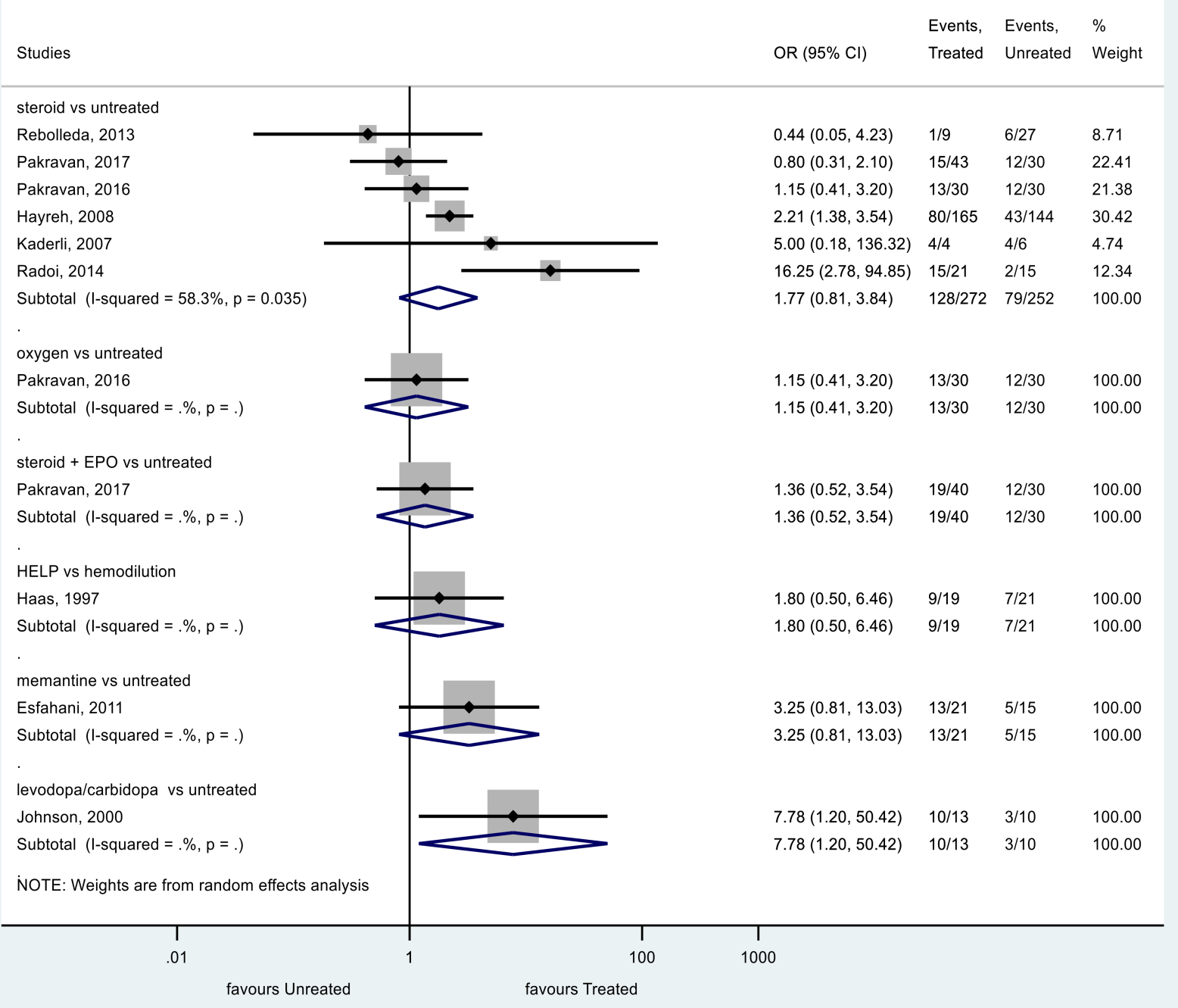

Figure 3. Comparison of interventions to no treatment regarding visual acuity (as a categorical variable).

\subsection{Effects of Therapies on Visual Field (VF)}

We analyzed the effect of treatments on VF in studies having at least 3 months of follow-up (Figure 4).

Steroids did not significantly improve VF compared to the control group $(p=0.853$, $\mathrm{WMD}=0.16,95 \% \mathrm{CI}:-1.54,1.86)$. There was no heterogeneity among these studies $\left(\mathrm{I}^{2}=0.0 \%, p=0.374\right)$.

Levodopa/carbidopa did not significantly improve VF compared to the control group $(p=0.596, \mathrm{WMD}=0.46,95 \% \mathrm{CI}:-1.23,2.15)$. Heterogeneity among these studies was very low $\left(\mathrm{I}^{2}=3.4 \%, p=0.309\right)$.

There was no significant improvement of VF after steroid plus EPO therapy, oxygen therapy, or memantine therapy.

Our results are represented in a summary table (Table 2). 


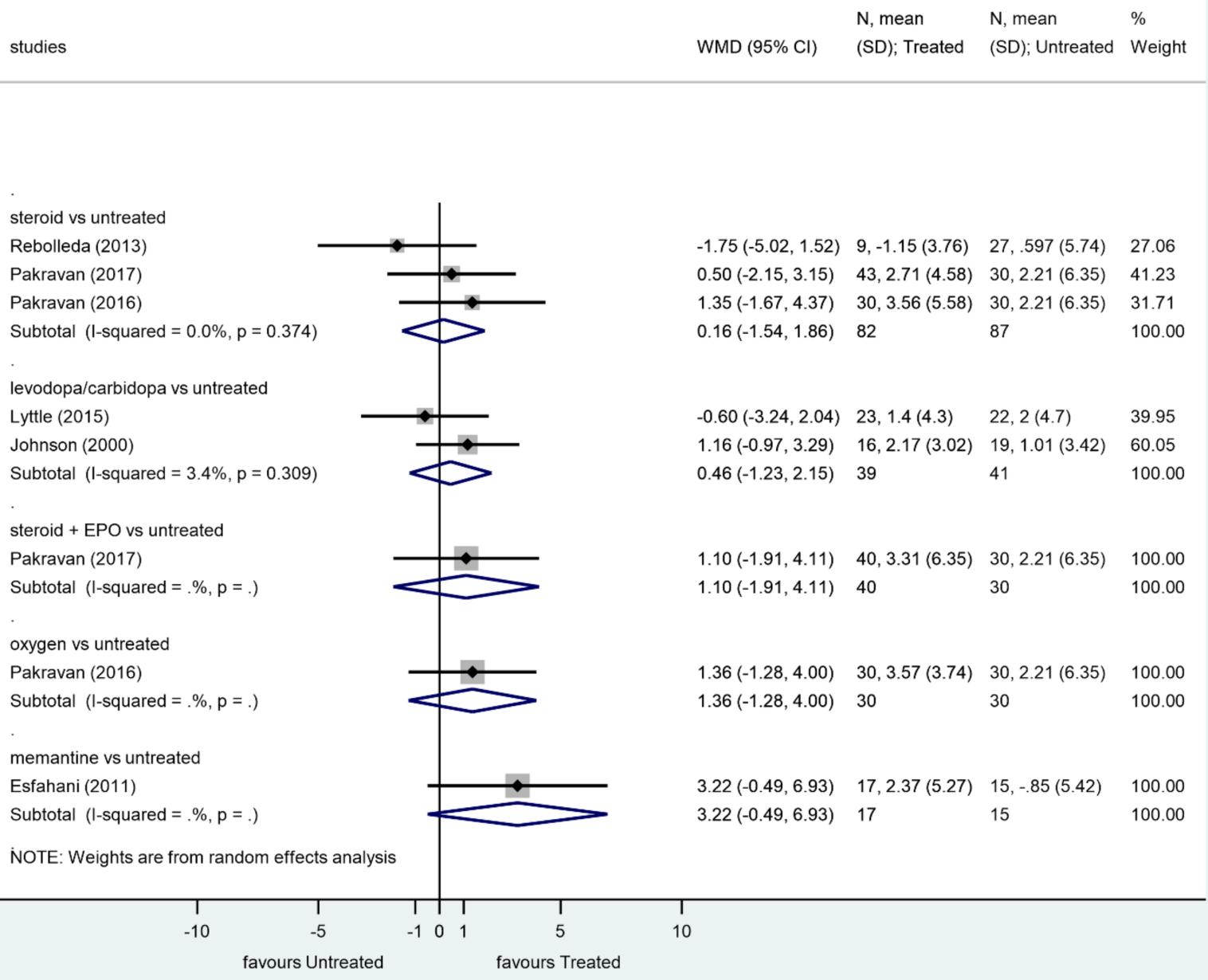

Figure 4. Comparison of interventions to no treatment regarding visual field.

Table 2. Summary table of results.

\begin{tabular}{cccc} 
Therapy & $\begin{array}{c}\text { VA (as Continuous } \\
\text { Variable) }\end{array}$ & $\begin{array}{c}\text { VA (as Categorical } \\
\text { Variable) }\end{array}$ & VF \\
\hline Steroid & Did not improve & Did not improve & Did not improve \\
\hline oxygen & Did not improve & Did not improve & Did not improve \\
\hline EPO+steroid & Did not improve & Did not improve & Did not improve \\
\hline memantine & Improved & Did not improve & Did not improve \\
\hline Levodopa/carbidopa & & Improved & Did not improve \\
\hline HELP & & Did not improve \\
\hline
\end{tabular}

\subsection{GRADE of Evidence, Risk of Bias Assessment, and Publication Bias}

The results of the evidence grading are shown in Tables 3-5. The results of the risk of bias assessment are shown in Supplementary Tables S1 and S2. 
Table 3. GRADE of evidence of our results for visual acuity as a continuous variable.

\begin{tabular}{|c|c|c|c|c|c|c|}
\hline \multirow{2}{*}{ Outcomes } & \multicolumn{2}{|c|}{ Anticipated Absolute Effects * $(95 \%$ CI $)$} & \multirow{2}{*}{$\begin{array}{c}\text { Relative } \\
\text { Effect } \\
(95 \% \mathrm{CI})\end{array}$} & \multirow{2}{*}{$\begin{array}{c}\text { No. of } \\
\text { Participants } \\
\text { (Studies) }\end{array}$} & \multirow{2}{*}{$\begin{array}{l}\text { Certainty of the } \\
\text { Evidence } \\
\text { (GRADE) }\end{array}$} & \multirow{2}{*}{ Comments } \\
\hline & Risk with Untreated & Risk with Treated & & & & \\
\hline $\begin{array}{l}\text { Steroid vs. } \\
\text { untreated } \\
\text { follow up: range } \\
6 \text { months to } \\
15 \text { months }\end{array}$ & $\begin{array}{c}\text { The mean steroid vs. } \\
\text { untreated was } 0 \\
\text { logMAR }\end{array}$ & $\begin{array}{l}\text { WMD } 0.14 \text { logMAR higher } \\
\text { (0.07 lower to } 0.35 \text { higher) }\end{array}$ & - & $\begin{array}{c}215 \\
\text { (5 observational } \\
\text { studies) }\end{array}$ & $\begin{array}{l}\oplus \bigcirc \bigcirc \bigcirc \\
\text { VERY LOW } \\
\text { a,b,c }\end{array}$ & \\
\hline $\begin{array}{l}\text { Oxygen vs. } \\
\text { untreated }\end{array}$ & $\begin{array}{l}\text { The mean oxygen vs. } \\
\text { untreated was } 0\end{array}$ & $\begin{array}{c}\text { WMD } 0.04 \text { lower } \\
\text { (0.26 lower to } 0.18 \text { higher })\end{array}$ & - & $\begin{array}{c}60 \\
(1 \mathrm{RCT})\end{array}$ & $\begin{array}{l}\oplus \bigcirc \bigcirc \bigcirc \\
\text { VERY LOW } \\
\text { d,e }\end{array}$ & \\
\hline $\begin{array}{l}\text { Steroid+EPO vs. } \\
\text { untreated }\end{array}$ & $\begin{array}{l}\text { The mean } \\
\text { steroid+EPO vs. } \\
\text { untreated was } 0\end{array}$ & $\begin{array}{c}\text { WMD } 0.02 \text { lower } \\
\text { (0.29 lower to } 0.25 \text { higher })\end{array}$ & - & $\begin{array}{c}70 \\
\text { (1 observational } \\
\text { study) }\end{array}$ & $\begin{array}{l}\oplus \bigcirc \bigcirc \bigcirc \\
\text { VERY LOW d,e }\end{array}$ & \\
\hline $\begin{array}{l}\text { Memantine vs. } \\
\text { untreated }\end{array}$ & $\begin{array}{l}\text { The mean memantine } \\
\text { vs. untreated was } 0\end{array}$ & $\begin{array}{c}\text { WMD } 0.48 \text { higher } \\
\text { (0.08 higher to } 0.88 \text { higher) }\end{array}$ & - & $\begin{array}{c}36 \\
(1 \mathrm{RCT})\end{array}$ & $\begin{array}{l}\oplus \bigcirc \bigcirc \bigcirc \\
\text { VERY LOW } \\
\text { d,e }\end{array}$ & \\
\hline
\end{tabular}

\section{GRADE Working Group grades of evidence}

High certainty: We are very confident that the true effect lies close to that of the estimate of the effect.

Moderate certainty: We are moderately confident in the effect estimate: The true effect is likely to be close to the estimate of the effect, but there is a possibility that it is substantially different.

Low certainty: Our confidence in the effect estimate is limited: The true effect may be substantially different from the estimate of the effect.

Very low certainty: We have very little confidence in the effect estimate: The true effect is likely to be substantially different from the estimate of effect.

Explanations: a. Among these 5 studies, there were 2 with low risk of bias, 2 with moderate, and 1 with serious risk of bias. b. Heterogeneity among the studies was substantial $(\mathrm{I} 2=63.5 \%, p=0.027)$. c. Interventions delivered differently in different settings. d. Not applicable. e. Low sample size. * The risk in the intervention group (and its $95 \%$ confidence interval) is based on the assumed risk in the comparison group and the relative effect of the intervention (and its 95\% CI). CI: Confidence interval.

Table 4. GRADE of evidence of our results for visual acuity as a categorical variable.

\begin{tabular}{|c|c|c|c|c|c|}
\hline \multirow{2}{*}{$\begin{array}{c}\text { Outcome } \\
\text { No. of Participants } \\
\text { (Studies) }\end{array}$} & \multirow{2}{*}{$\begin{array}{l}\text { Relative Effect } \\
\qquad(95 \% \text { CI })^{*}\end{array}$} & \multicolumn{3}{|c|}{ Anticipated Absolute Effects (95\% CI) } & \multirow{2}{*}{ Certainty } \\
\hline & & Control & Treated & Difference & \\
\hline $\begin{array}{l}\text { Steroid vs. untreated-assessed as a } \\
\text { categorical variable (Visual Acuity) } \\
\text { follow up: range } 6 \text { months to } 15 \text { months } \\
\text { № of participants: } 544 \\
\text { (6 observational studies) }\end{array}$ & $\begin{array}{c}\text { OR } 1.77 \\
(0.81 \text { to } 3.84)\end{array}$ & $29.0 \%$ & $\begin{array}{c}42.0 \% \\
(24.9 \text { to } 61.1)\end{array}$ & $\begin{array}{c}13.0 \% \text { more } \\
\text { (4.1 fewer to } 32.1 \text { more) }\end{array}$ & $\begin{array}{l}\oplus \bigcirc \bigcirc \bigcirc \\
\text { VERY LOW a,b,c }\end{array}$ \\
\hline $\begin{array}{l}\text { Oxygen vs. untreated } \\
\text { № of participants: } 60 \\
\text { (1 RCT) }\end{array}$ & $\begin{array}{c}\text { OR } 1.15 \\
(0.41 \text { to } 3.20)\end{array}$ & $40.0 \%$ & $\begin{array}{c}43.4 \% \\
(21.5 \text { to } 68.1)\end{array}$ & $\begin{array}{c}3.4 \% \text { more } \\
\text { (18.5 fewer to } 28.1 \text { more) }\end{array}$ & $\begin{array}{l}\oplus \bigcirc \bigcirc \bigcirc \\
\text { VERY LOW d,e }\end{array}$ \\
\hline $\begin{array}{l}\text { Steroid+EPO vs. untreated } \\
\text { № of participants: } 70 \\
\text { (1 observational study) }\end{array}$ & $\begin{array}{c}\text { OR } 1.36 \\
(0.52 \text { to } 3.54)\end{array}$ & $40.0 \%$ & $\begin{array}{c}47.6 \% \\
(25.7 \text { to } 70.2)\end{array}$ & $\begin{array}{c}7.6 \% \text { more } \\
\text { (14.3 fewer to } 30.2 \text { more) }\end{array}$ & $\begin{array}{l}\oplus \bigcirc \bigcirc \bigcirc \\
\text { VERY LOW d,e }\end{array}$ \\
\hline $\begin{array}{l}\text { HELP vs. hemodilution } \\
\text { № of participants: } 40 \\
\text { (1 observational study) }\end{array}$ & $\begin{array}{c}\text { OR } 1.80 \\
(0.50 \text { to } 6.46)\end{array}$ & $33.3 \%$ & $\begin{array}{c}47.4 \% \\
(20 \text { to } 76.4)\end{array}$ & $\begin{array}{c}14.0 \% \text { more } \\
\text { (13.3 fewer to } 43 \text { more) }\end{array}$ & $\begin{array}{l}\oplus \bigcirc \bigcirc \bigcirc \\
\text { VERY LOW d,e }\end{array}$ \\
\hline $\begin{array}{l}\text { Memantine vs. untreated } \\
\text { № of participants: } 36 \\
\text { (1 RCT) }\end{array}$ & $\begin{array}{c}\text { OR } 3.25 \\
(0.81 \text { to } 13.30)\end{array}$ & $33.3 \%$ & $\begin{array}{c}61.9 \% \\
(28.8 \text { to } 86.9)\end{array}$ & $\begin{array}{c}28.6 \% \text { more } \\
\text { (4.5 fewer to } 53.6 \text { more) }\end{array}$ & $\begin{array}{l}\oplus \bigcirc \bigcirc \bigcirc \\
\text { VERY LOW d,e }\end{array}$ \\
\hline $\begin{array}{c}\text { Levodopa/carbidopa vs. untreated } \\
\text { № of participants: } 23 \\
\text { (1 observational study) }\end{array}$ & $\begin{array}{c}\text { OR } 7.78 \\
(1.20 \text { to } 50.42)\end{array}$ & $30.0 \%$ & $\begin{array}{c}76.9 \% \\
(34 \text { to } 95.6)\end{array}$ & $\begin{array}{c}46.9 \% \text { more } \\
\text { (4 more to } 65.6 \text { more) }\end{array}$ & $\begin{array}{l}\oplus \bigcirc \bigcirc \bigcirc \\
\text { VERY LOW d,e }\end{array}$ \\
\hline
\end{tabular}

GRADE Working Group grades of evidence

High certainty: We are very confident that the true effect lies close to that of the estimate of the effect.

Moderate certainty: We are moderately confident in the effect estimate: The true effect is likely to be close to the estimate of the effect, but there is a possibility that it is substantially different.

Low certainty: Our confidence in the effect estimate is limited: The true effect may be substantially different from the estimate of the effect.

Very low certainty: We have very little confidence in the effect estimate: The true effect is likely to be substantially different from the estimate of effect.

Explanations: a. Among these 6 studies, there were 3 with low risk of bias, 2 with moderate, and 1 with serious risk of bias. $\mathrm{b}$. Heterogeneity among the studies was moderate ( $\mathrm{I} 2=58.3 \%, p=0.035$ ) probably due to the differences in the intervention and study designs. c. Interventions delivered differently in different settings. d. Not applicable. e. Low sample size. ${ }^{*}$ The risk in the intervention group (and its $95 \%$ confidence interval) is based on the assumed risk in the comparison group and the relative effect of the intervention (and its 95\% CI). CI: Confidence interval; OR: Odds ratio. 
Table 5. GRADE of evidence of our results for visual field.

\begin{tabular}{|c|c|c|c|c|c|c|}
\hline \multirow[b]{2}{*}{ Outcomes } & \multicolumn{2}{|c|}{ Anticipated Absolute Effects * $(95 \%$ CI $)$} & \multirow{2}{*}{$\begin{array}{l}\text { Relative } \\
\text { Effect } \\
(95 \% \text { CI })\end{array}$} & \multirow{2}{*}{$\begin{array}{l}\text { No. of Participants } \\
\text { (Studies) }\end{array}$} & \multirow{2}{*}{$\begin{array}{l}\text { Certainty of } \\
\text { the Evidence } \\
\text { (GRADE) }\end{array}$} & \multirow[b]{2}{*}{ Comments } \\
\hline & Risk with Untreated & $\begin{array}{l}\text { Risk with } \\
\text { Treatment }\end{array}$ & & & & \\
\hline $\begin{array}{l}\text { Pentoxiphilline+steroid } \\
\text { vs. pentoxyphilline }\end{array}$ & $\begin{array}{l}\text { The mean pentox- } \\
\text { iphilline+steroid vs. } \\
\text { pentoxyphilline was } 0\end{array}$ & $\begin{array}{l}\text { WMD } 3.2 \text { lower } \\
\text { (4 lower to } \\
2.4 \text { lower) }\end{array}$ & - & $\begin{array}{c}49 \\
\text { (1 observational study) }\end{array}$ & $\begin{array}{l}\oplus \bigcirc \bigcirc \bigcirc \\
\text { VERY LOW } \\
\text { a,b,c }\end{array}$ & \\
\hline Steroid vs. untreated & $\begin{array}{l}\text { The mean steroid vs. } \\
\text { untreated was } 0\end{array}$ & $\begin{array}{l}\text { WMD } 0.16 \text { higher } \\
\text { (1.54 lower to } \\
1.86 \text { higher })\end{array}$ & - & $\begin{array}{c}169 \\
\text { (3 observational studies) }\end{array}$ & $\begin{array}{l}\oplus \oplus \bigcirc \bigcirc \\
\mathrm{LOW}^{\mathrm{c}, \mathrm{d}}\end{array}$ & \\
\hline $\begin{array}{c}\text { Levodopa/carbidopa } \\
\text { vs. untreated }\end{array}$ & $\begin{array}{c}\text { The mean } \\
\text { levodopa/carbidopa } \\
\text { vs. untreated was } 0\end{array}$ & $\begin{array}{l}\text { WMD } 0.46 \text { higher } \\
\text { (1.23 lower to } \\
2.15 \text { higher })\end{array}$ & - & $\begin{array}{c}80 \\
\text { (2 observational studies) }\end{array}$ & $\begin{array}{l}\oplus \bigcirc \bigcirc \bigcirc \\
\text { VERY LOW }\end{array}$ & \\
\hline $\begin{array}{l}\text { Steroid+EPO vs. } \\
\text { untreated }\end{array}$ & $\begin{array}{l}\text { The mean } \\
\text { steroid+EPO vs. } \\
\text { untreated was } 0\end{array}$ & $\begin{array}{l}\text { WMD } 1.1 \text { higher } \\
\text { (1.91 lower to } \\
4.11 \text { higher })\end{array}$ & - & $\begin{array}{c}70 \\
\text { (1 observational study) }\end{array}$ & $\begin{array}{l}\oplus \bigcirc \bigcirc \bigcirc \\
\text { VERY LOW }\end{array}$ & \\
\hline Oxygen vs. untreated & $\begin{array}{l}\text { The mean oxygen vs. } \\
\text { untreated was } 0\end{array}$ & $\begin{array}{l}\text { WMD } 1.36 \text { higher } \\
\text { (1.28 lower to } \\
4 \text { higher })\end{array}$ & - & $\begin{array}{c}60 \\
(1 \mathrm{RCT})\end{array}$ & $\begin{array}{l}\oplus \bigcirc \bigcirc \bigcirc \\
\text { VERY LOW }\end{array}$ & \\
\hline $\begin{array}{l}\text { Memantine vs. } \\
\text { untreated }\end{array}$ & $\begin{array}{l}\text { The mean memantine } \\
\text { vs. untreated was } 0\end{array}$ & $\begin{array}{l}\text { WMD } 3.22 \text { higher } \\
\text { (0.49 lower to } \\
6.93 \text { higher })\end{array}$ & - & $\begin{array}{c}32 \\
(1 \mathrm{RCT})\end{array}$ & $\begin{array}{l}\oplus \bigcirc \bigcirc \bigcirc \\
\text { VERY LOW }\end{array}$ & \\
\hline
\end{tabular}

GRADE Working Group grades of evidence

High certainty: We are very confident that the true effect lies close to that of the estimate of the effect.

Moderate certainty: We are moderately confident in the effect estimate: The true effect is likely to be close to the estimate of the effect, but there is a possibility that it is substantially different.

Low certainty: Our confidence in the effect estimate is limited: The true effect may be substantially different from the estimate of the effect.

Very low certainty: We have very little confidence in the effect estimate: The true effect is likely to be substantially different from the estimate of effect.

Explanations: a. Moderate risk of bias. b. Not applicable. c. Low sample size. $\mathrm{d}$. There were minor differences in the dosage of the steroid therapy. e. As the results of our risk of bias assessment, both of the studies are at moderate risk of bias. ${ }^{*}$ The risk in the intervention group (and its $95 \%$ confidence interval) is based on the assumed risk in the comparison group and the relative effect of the intervention (and its 95\% CI). CI: Confidence interval.

In case of VA as a continuous variable, due to low study numbers, publication bias was assessed only in the group of studies with steroid therapy. The result of the visual assessment and test of H0 ( $p=0.926)$ revealed no small study effect (Supplementary Figure S2). Similarly, the result of the visual assessment of the funnel plot and test of H0 ( $p=0.983)$ revealed no small study effect in case of VA as a categorical variable (Supplementary Figure S3). We could not assess the publication bias in case of VF, due to the low number of studies.

\section{Discussion}

In our systematic review and meta-analysis, we summarized the findings that are currently available in clinical literature of the effects of therapeutic modalities on the outcomes of NAION.

\subsection{Steroid and NAION}

Corticosteroids have antiedematous, antiphlogistic effects, can decrease capillary permeability, and decrease compression of capillaries in the optic nerve head, improving blood flow and restore the function of surviving ischemic axons in NAION. [43] Our meta-analysis of 6 studies for VA and 3 for VF demonstrated that steroids did not improve VA and VF significantly. However, the results of a study by Hayreh et al. [10] provided support for the beneficial effect of steroids. They found that oral corticosteroid therapy resulted in a significantly higher probability of improvement in VA. Two studies with intravitreal steroid therapy (triamcinolone injection) [8,9] showed significant improvement of VA and VF, although one of them had a small number of cases [9]. The effect of steroid and pentoxifylline was also described in a study showing that fluocortolone in combination 
with pentoxifylline has a beneficial effect on VA, but there was no significant difference in the VF [14]. In contrast to the aforementioned studies, Rebolleda et al. and Kinori et al. reported no functional difference between the steroid and the untreated groups [4,6]. Moreover, a randomized, double-blind clinical trial supports our findings, as it concluded that steroids did not improve the VA significantly at 6 months. Unfortunately, we could not include this study in our meta-analysis due to missing data about the initial and final VA and VF values of the patient groups [11]. Pakravan et al. evaluated the efficacy of normobaric oxygen therapy in addition to steroids [1]. Their findings did not reveal beneficial effects of either steroids or oxygen for the management of NAION compared to placebo. Steigerwalt et al. used PGE1 with steroids [7], but we did not include it in our analysis because the control group also received steroids. They found that VA improved in the cases treated with PGE1 compared to the control group. We found a meta-analysis published by Chen et al. which investigated only steroid therapy in NAION. Their article also supports the results of our meta-analysis, that steroids do not significantly improve VA [43]. Our meta-analysis investigated not only steroid therapy but we also examined the VF in addition to VA. Our results suggest that steroids did not significantly improve VA or VF in NAION.

\subsection{Levodopa/Carbidopa and NAION}

Levodopa crosses the blood-retinal barrier to increase retinal dopamine level. Dopamine is a neurotransmitter, neuromodulator, and neuroprotective agent. There are some studies about the effects of levodopa on visual function in patients with NAION. Lyttle et al. found that levodopa improved central VA [18]. Johnson et al. [17] published VA improvement results in patients with $20 / 40$ VA or worse, $76.9 \%$ in the levodopa group and $30 \%$ of the control group had improved VA. Johnson et al. [15] found improvement of VA among patients receiving levodopa and carbidopa despite a long-standing visual loss; however, this study refers to earlier publications, which stated that visual improvement might have been occurred because of the spontaneous resolution of NAION. In contrast with what Johnson found, in the study by Simsek et al., there was no improvement in VA either in the study or the placebo group, suggesting that levodopa and carbidopa therapy cannot restore a long-standing visual loss [16]. Unfortunately, these studies could not meet our eligibility criteria for the quantitative synthesis, therefore we could not perform the meta-analysis of their results.

\subsection{EPO and NAION}

Moderres et al. published a study where 31 patients received intravitreal injection of erythropoietin solution and it showed improvement in VA. Neuroprotection is a therapeutic strategy in the treatment of NAION. EPO reduces apoptosis in retinal ganglion cells [19]. Pakravan et al. [5] compared the effect of steroid therapy alone or in combination with systemic EPO for the treatment of NAION. They found no beneficial effect in either group, similar to our results.

\subsection{Brimonidine and NAION}

Topical brimonidine tartrate is an alpha-adrenergic agonist agent, which has a neuroprotective effect for retinal ganglion cells. We found two studies $[20,21]$ that examined the effects of brimonidine tartrate as a treatment of NAION, but they did not find an improvement of visual function. Wilhelm's double-masked, randomized, placebo-controlled trial was not included in our analysis due to the ambiguity in the patient number in the treatment groups.

\subsection{Memantine and NAION}

Memantine is a noncompetitive NMDA receptor antagonist and it relieves glutamate NMDA-receptor mediated toxicity in retinal ganglion cells. Analyzing the results 
of Esfahani et al. [22] as a continuous variable we found that memantine improves VA compared to the control group.

\subsection{Heparin-Induced Extracorporeal LDL/Fibrinogen Precipitation and NAION}

HELP improves rheologic status of tissues. We found four publications about HELP and hemodilution [24-26,40]; one of these was analyzed statistically, a prospective, randomized, controlled study by Haas et al., which suggested the HELP system is more effective than hemodilution in the treatment of NAION.

\subsection{Anticoagulants and Thrombolytics}

Multiple embolization may play a role in the development of NAION. We found publications investigating the efficacy of anticoagulants and thrombolytics. The recanalization rate in response to thrombolytic therapy improves as a vessel narrows [44]. Aftab et al. found that patients with NAION did benefit from anticoagulation with heparin and warfarin [23].

\subsection{Limitations}

We found few studies that we could use in quantitative analysis. There are no large uniform multicenter studies to compare. We included only two RCTs in addition to other comparative studies in our quantitative analysis of steroid therapy. Most of them had a small sample size and there were differences in the route, administration intervals and dosage of interventions. These differences probably explain the moderate data heterogeneity among these studies. As mentioned before, two studies [10,17] did not report the change in VA of their patients with VA better than 20/40, therefore we were unable to include these data in our meta-analysis. This could explain the heterogeneity in our results in that group.

\section{Conclusions}

There are many medical therapies in practice, but based on our meta-analysis and systematic review, we did not find the drug that is generally recommended. Further randomized, controlled trials are necessary to find the most effective therapy for NAION. NAION has a number of etiological factors and there may be no general therapeutic option. Subgroups of different etiologies should be considered separately.

With eliminating general cardiovascular predisposing factors, we can reduce the incidence of NAION.

Further human investigation and animal experiences are needed to help us to understand the earliest pathological processes and to find the effective therapy for NAIONs.

Supplementary Materials: The following supporting information can be downloaded at: https: / / www.mdpi.com/article/10.3390/ijerph19052718/s1, Table S1. Results of risk of bias assessement of randomized trials with RoB 2; Table S2. Results of risk of bias assessment in non-randomized trials with ROBIN-I tool; Figure S1. Forest plot of visual acuity, without Hayreh et al. (as a categorical variable); Figure S2. Funnel plot of visual acuity, as a continuous variable; Figure S3. Funnel plot of visual acuity, as a categorical variable

Author Contributions: Conceptualization: K.L., V.G., Z.R.D., S.K., Z.S. and P.H.; methodology: K.L., V.G., Z.R.D., S.K. and Z.S.; validation: K.L., V.G., Z.R.D., S.K. and Z.S.; formal analysis: N.F.; investigation: K.L., V.G., Z.R.D., S.K. and Z.S.; data curation: K.L., V.G., Z.R.D., S.K., Z.S. and N.F.; writing-original draft preparation: K.L., V.G., Z.R.D., S.K. and Z.S.; writing-review and editing: A.G., G.V., L.L., K.L., R.K. and G.F.; visualization: K.L., V.G., Z.R.D., S.K., Z.S. and G.F. All authors have read and agreed to the published version of the manuscript.

Funding: This work was supported by the Economic Development and Innovation Operative Program Grant (GINOP-2.3.4-15-2020-00010); and by the Human Resources Development Operational Program Grant (EFOP-3.6.1-16-2016-00004).

Institutional Review Board Statement: Not applicable. 
Informed Consent Statement: Not applicable.

Acknowledgments: This research was not a company-initiated study. Sponsors were not involved in the design, data collection, analysis, interpretation, or preparation of the manuscript.

Conflicts of Interest: The authors declare that the research was conducted in the absence of any commercial or financial relationships that could be construed as a potential conflict of interest.

\section{References}

1. Pakravan, M.; Sanjari, N.; Esfandiari, H.; Pakravan, P.; Yaseri, M. The effect of high-dose steroids, and normobaric oxygen therapy, on recent onset non-arteritic anterior ischemic optic neuropathy: A randomized clinical trial. Graefe's Arch. Clin. Exp. Ophthalmol. 2016, 254, 2043-2048. [CrossRef] [PubMed]

2. Judit Somlai, T.K.E. Neuro-Ophthalmology, Vascular Diseases of the Optic Nerve: The Neuro-Ophthalmologist's Approach; Springer International Publishing: Cham, Switzerland, 2016; p. 395.

3. Atkins, E.J.; Bruce, B.; Newman, N.J.; Biousse, V. Treatment of Nonarteritic Anterior Ischemic Optic Neuropathy. Surv. Ophthalmol. 2010, 55, 47-63. [CrossRef] [PubMed]

4. Rebolleda, G.; Pérez-López, M.; Casas-Llera, P.; Contreras, I.; Muñoz-Negrete, F.J. Visual and anatomical outcomes of non-arteritic anterior ischemic optic neuropathy with high-dose systemic corticosteroids. Graefe's Arch. Clin. Exp. Ophthalmol. 2013, 251, 255-260. [CrossRef] [PubMed]

5. Pakravan, M.; Esfandiari, H.; Hassanpour, K.; Razavi, S.; Pakravan, P. The Effect of Combined Systemic Erythropoietin and Steroid on Non-arteritic Anterior Ischemic Optic Neuropathy: A Prospective Study. Curr. Eye Res. 2017, 42, 1079-1084. [CrossRef] [PubMed]

6. Kinori, M.; Ben-Bassat, I.; Wasserzug, Y.; Chetrit, A.; Huna-Baron, R. Visual outcome of mega-dose intravenous corticosteroid treatment in non-arteritic anterior ischemic optic neuropathy-retrospective analysis. BMC Ophthalmol. 2014, 14, 62. [CrossRef]

7. Steigerwalt, R.D.; Cesarone, M.R.; Belcaro, G.; Pascarella, A.; De Angelis, M.; Bacci, S. Nonarteritic anterior ischemic optic neuropathy treated with intravenous prostaglandin E1 and steroids. Int. J. Angiol. 2008, 17, 193-196. [CrossRef]

8. Radoi, C.; Garcia, T.; Brugniart, C.; Ducasse, A.; Arndt, C. Intravitreal triamcinolone injections in non-arteritic anterior ischemic optic neuropathy. Graefe's Arch. Clin. Exp. Ophthalmol. 2013, 252, 339-345. [CrossRef]

9. Kaderli, B.; Avci, R.; Yucel, A.; Guler, K.; Gelisken, O. Intravitreal Triamcinolone Improves Recovery of Visual Acuity in Nonarteritic Anterior Ischemic Optic Neuropathy. J. Neuro-Ophthalmol. 2007, 27, 164-168. [CrossRef] [PubMed]

10. Hayreh, S.S.; Zimmerman, M.B. Non-arteritic anterior ischemic optic neuropathy: Role of systemic corticosteroid therapy. Graefe's Arch. Clin. Exp. Ophthalmol. 2008, 246, 1029-1046. [CrossRef]

11. Saxena, R.; Singh, D.; Sharma, M.; James, M.; Sharma, P.; Menon, V. Steroids versus No Steroids in Nonarteritic Anterior Ischemic Optic Neuropathy: A Randomized Controlled Trial. Ophthalmology 2018, 125, 1623-1627. [CrossRef]

12. Vidović, T.; Cerovski, B.; Perić, S.; Kordić, R.; Mrazovac, D. Corticosteroid therapy in patients with non-arteritic anterior ischemic optic neuropathy. Coll. Antropol. 2015, 39, 63-66.

13. Yaman, A.; Selver, O.B.; Saatci, A.O.; Soylev, M.F. Intravitreal triamcinolone acetonide injection for acute non-arteritic anterior ischaemic optic neuropathy. Clin. Exp. Optom. 2008, 91, 561-564. [CrossRef] [PubMed]

14. Prokosch, V.; Thanos, S. Visual outcome of patients following NAION after treatment with adjunctive fluocortolone. Restor. Neurol. Neurosci. 2014, 32, 381-389. [CrossRef] [PubMed]

15. Johnson, L.N.; Gould, T.J.; Krohel, G.B. Effect of Levodopa and Carbidopa on Recovery of Visual Function in Patients With Nonarteritic Anterior Ischemic Optic Neuropathy of Longer Than Six Months' Duration. Am. J. Ophthalmol. 1996, 121, 77-83. [CrossRef]

16. Simsek, T.; Eryilmaz, T.; Acaroglu, G. Efficacy of levodopa and carbidopa on visual function in patients with non-arteritic anterior ischaemic optic neuropathy. Int. J. Clin. Pr. 2005, 59, 287-290. [CrossRef]

17. Johnson, L.N.; E Guy, M.; Krohel, G.B.; Madsen, R.W. Levodopa may improve vision loss in recent-onset, nonarteritic anterior ischemic optic neuropathy. Ophthalmology 2000, 107, 521-526. [CrossRef]

18. Lyttle, D.P.; Johnson, L.N.; Margolin, E.A.; Madsen, R.W. Levodopa as a possible treatment of visual loss in nonarteritic anterior ischemic optic neuropathy. Graefe's Arch. Clin. Exp. Ophthalmol. 2016, 254, 757-764. [CrossRef]

19. Modarres, M.; Falavarjani, K.G.; Nazari, H.; Sanjari, M.S.; Aghamohammadi, F.; Homaii, M.; Samiy, N. Intravitreal erythropoietin injection for the treatment of non-arteritic anterior ischaemic optic neuropathy. Br. J. Ophthalmol. 2011, 95, 992-995. [CrossRef]

20. Fazzone, H.E.; Kupersmith, M.J.; Leibmann, J. Does topical brimonidine tartrate help NAION? Br. J. Ophthalmol. 2003, 87, 1193-1194. [CrossRef]

21. The BRAION study group; Wilhelm, B.; Lüdtke, H.; Wilhelm, H. Efficacy and tolerability of $0.2 \%$ brimonidine tartrate for the treatment of acute non-arteritic anterior ischemic optic neuropathy (NAION): A 3-month, double-masked, randomised, placebo-controlled trial. Graefe's Arch. Clin. Exp. Ophthalmol. 2005, 244, 551-558. [CrossRef]

22. Riazi, E.M.; Aalami, H.Z.; Kiumehr, S.; Gholmi, A.; Tabasi, A.; Piri, N.; Mirshahi, A.; Nili, A.M.; Movassat, M.; Fakhraee, G. Memantine treatment in acute nonarteric anterior ischemic optic neuropathy: A Randomized Clinical Trial. J. Curr. Ophthalmol. 2011, 23, 11-20. 
23. Aftab, A.M.; Iqbal, M.; Rauf, A.; Ali, A. Non arteritic anterior ischemic optic neuropathy; does Anticoagulation help? J. Ayub Med Coll. Abbottabad 2017, 28, 776-780.

24. Haas, A.; Walzl, M.; Jesenik, F.; Walzl, B.; Berghold, A.; Berglöff, J.; Feigl, B.; Faulborn, J. Application of HELP in nonarteritic anterior ischemic optic neuropathy: A prospective, randomized, controlled study. Graefe's Arch. Clin. Exp. Ophthalmol. 1997, 235, 14-19. [CrossRef] [PubMed]

25. Ramunni, A.; Giancipoli, G.; Guerriero, S.; Lapenna, L.; Saracino, A.; Saliani, M.T.; Capurso, A.; Sborgia, C.; Coratelli, P. LDLApheresis Accelerates the Recovery of Nonarteritic Acute Anterior Ischemic Optic Neuropathy. Ther. Apher. Dial. 2005, 9, 53-58. [CrossRef] [PubMed]

26. Guerriero, S.; Giancipoli, G.; Cantatore, A.; Sacco, G.; Brescia, P.; Saliani, M.T.; Ramunni, A.; Guerriero, G.G.S. LDL apheresis in the treatment of non-arteritic ischaemic optic neuropathy: A 6-month follow-up study. Eye 2008, 23, 1343-1344. [CrossRef] [PubMed]

27. Bajin, M.S.; Selver, O.B.; Taskin, O.; Yaman, A.; Saatci, A.O. Single intravitreal ranibizumab injection in eyes with acute non-arteritic anterior ischaemic optic neuropathy. Clin. Exp. Optom. 2011, 94, 367-370. [CrossRef] [PubMed]

28. Saatci, A.O.; Taskin, O.; Selver, O.B.; Yaman, A.; Bajin, M.S. Efficacy of Intravitreal Ranibizumab Injection in Acute Nonarteritic Ischemic Optic Neuropathy: A Long-Term Follow Up§. Open Ophthalmol. J. 2013, 7, 58-62. [CrossRef]

29. Rootman, D.B.; Gill, H.S.; A Margolin, E. Intravitreal bevacizumab for the treatment of nonarteritic anterior ischemic optic neuropathy: A prospective trial. Eye 2013, 27, 538-544. [CrossRef]

30. Moher, D.; Shamseer, L.; Clarke, M.; Ghersi, D.; Liberati, A.; Petticrew, M.; Shekelle, P.; Stewart, L.A.; PRISMA-P Group. Preferred reporting items for systematic review and meta-analysis protocols (PRISMA-P) 2015 statement. Syst. Rev. 2015, 4, 1. [CrossRef]

31. Higgins, J.P.; Thomas, J.; Chandler, J.; Cumpston, M.; Li, T.; Page, M.J.; Welch, V.A. (Eds.) Cochrane Handbook for Systematic Reviews of Interventions; Version 6.1; updated September 2020; Cochrane: Oxford, UK, 2020.

32. DerSimonian, R.; Laird, N. Meta-analysis in clinical trials. Control. Clin. Trials 1986, 7, 177-188. [CrossRef]

33. Holladay, J.T. Proper method for calculating average visual acuity. J. Refract. Surg. 1997, 13, 388-391. [CrossRef]

34. Sweeting, M.J.; Sutton, A.; Lambert, P.C. What to add to nothing? Use and avoidance of continuity corrections in meta-analysis of sparse data. Stat. Med. 2004, 23, 1351-1375. [CrossRef] [PubMed]

35. Higgins, J.P.; Altman, D.G.; Gøtzsche, P.C.; Jüni, P.; Moher, D.; Oxman, A.D.; Savović, J.; Schulz, K.F.; Weeks, L.; Sterne, J.A. The Cochrane Collaboration's tool for assessing risk of bias in randomised trials. BMJ 2011, 343, d5928. [CrossRef] [PubMed]

36. Sterne, J.A.; Hernán, M.A.; McAleenan, A.; Reeves, B.C.; Higgins, J.P. Chapter 25: Assessing risk of bias in a non-randomized study. In Cochrane Handbook for Systematic Reviews of Interventions version 6.1 (updated September 2020); Higgins, J.P.T., Thomas, J., Chandler, J., Cumpston, M., Li, T., Page, M.J., Welch, V.A., Eds.; Cochrane: Oxford, UK, 2020.

37. Guyatt, G.H.; Oxman, A.D.; Vist, G.E.; Kunz, R.; Falck-Ytter, Y.; Alonso-Coello, P.; Schünemann, H.J. GRADE: An emerging consensus on rating quality of evidence and strength of recommendations. BMJ 2008, 336, 924-926. [CrossRef] [PubMed]

38. Hayreh, S.S.; Zimmerman, M.B. Nonarteritic Anterior Ischemic Optic Neuropathy: Natural History of Visual Outcome. Ophthalmology 2008, 115, 298-305.e2. [CrossRef] [PubMed]

39. Prescott, C.R.; Sklar, C.A.; Lesser, R.L.; Adelman, R.A. Is Intravitreal Bevacizumab an Effective Treatment Option for Nonarteritic Anterior Ischemic Optic Neuropathy? J. Neuro-Ophthalmol. 2012, 32, 51-53. [CrossRef]

40. Haas, A.; Uyguner, I.; Sochor, G.; Schmut, O.; Vidic, B.; Faulborn, J. Nichtarteriitische vordere ischämische Optikusneuropathie: Langzeitergebnisse nach Hämodilutionstherapie. Klin. Mon. Für Augenheilkd. 1994, 205, 143-146. [CrossRef]

41. Bojić, L.; Kovacević, H.; Andrić, D.; Karaman-Kraljević, K.; Cagalj, S. The effects of hyperbaric oxygen on visual functions in ischaemic optic neuropathy. Arch. Ind. Hyg. Toxicol. 1994, 45, 19-24.

42. Sanjari, N.; Pakravan, M.; Nourinia, R.; Esfandiari, H.; Hafezi-Moghadam, A.; Zandi, S.; Nakao, S.; Shah-Heidari, M.-H.; Jamali, A.; Yaseri, M.; et al. Intravitreal Injection of a Rho-Kinase Inhibitor (Fasudil) for Recent-Onset Nonarteritic Anterior Ischemic Optic Neuropathy. J. Clin. Pharmacol. 2015, 56, 749-753. [CrossRef]

43. Chen, J.; Zhu, J.; Chen, L.; Hu, C.; Du, Y. Steroids in the treatment of nonarteritic anterior ischemic optic neuropathy: A PRISMAcompliant meta-analysis. Medicine (Baltimore) 2019, 98, e17861. [CrossRef]

44. Mac Grory, B.; Lavin, P.; Kirshner, H.; Schrag, M. Thrombolytic Therapy for Acute Central Retinal Artery Occlusion. Stroke 2020, 51, 687-695. [CrossRef] [PubMed] 